\title{
SINTOMAS ATÍPICOS EM FRUTOS DE MELOEIRO E DE MELANCIA OCASIONADOS POR Watermelon mosaic virus-2
}

\author{
J. ALBÉRSIO A. LIMA ${ }^{1}$, M. ABÍLIO DE QUEIROZ ${ }^{2}$, \\ NAJARA F. RAMOS ${ }^{1} \&$ M. FÁTIMA B. GONÇALVES ${ }^{1}$
}

${ }^{1}$ Laboratório de Virologia Vegetal, Departamento de Fitotecnia, Universidade Federal do Ceará, Cx. Postal 6046, CEP

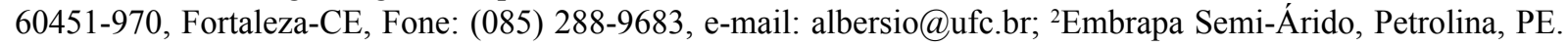

(Aceito para publicação em 24/09/2002)

Autor para correspondência: J. Albérsio A. Lima

\section{ABSTRACT \\ Atypic symptoms in melon and watermelon fruits caused by Watermelon mosaic virus-2}

The Northeast of Brazil presents great potencial for melon (Cucumis melo) and watermelon (Citrullus lanatus) production. Melon fruit with white spots and watermelon fruits showing chlorotic spots were demonstrated to be caused by Watermelon mosaic virus-2, through indirect enzyme linked-immuno sorbent assay.
A cultura do meloeiro (Cucumis melo L.) e da melancia [Citrullus lanatus (Thumb). Matsum \& Nakai] ocupam importantes posições na agricultura irrigada dos estados da região Nordeste do Brasil. No entanto, estas cucurbitáceas estão sujeitas a muitos problemas sanitários, dentre os quais se destacam as doenças ocasionadas por vírus que comprometem seriamente a qualidade e a quantidade dos produtos.

Os vírus de maior importância para as cucurbitáceas no Brasil pertencem à família Potyviridae, gênero Potyvirus e, de acordo com estudos de avaliação de graus de incidência de vírus em meloeiro e em melancia no Nordeste (Oliveira et al. Fitopatologia Brasileira 25:628. 2000), o Watermelon mosaic virus-2 (WMV-2) é o vírus de maior predominância no pólo de irrigação de Petrolina/Juazeiro (PE/BA).

No presente trabalho, frutos de plantas da cultivar AF682 de meloeiro apresentando sintomas de mancha branca (Figura 1A) e do híbrido Tiffany, sem sementes, de melancia, com sintomas de bolhosidades e manchas cloróticas (Figura 1B) foram constatados em áreas irrigadas de Petrolina/ Juazeiro. Análises sorológicas enzyme linked-immuno sorbent assay (ELISA) indireto revelaram a presença de WMV-2 em todas as amostras de folhas e de frutos coletados. Inspeções de campo, confirmadas por ELISA, indicaram a constante presença dos sintomas nos frutos de plantas de meloeiro e de melancia infetadas por WMV-2. Estudos de campo demonstraram, também, larga dispersão dos frutos com sintomas (Figura 1) em plantios comerciais de meloeiro, prejudicando a comercialização dos mesmos e impedindo sua exportação. Plantas sem sintomas nas folhas e negativas em testes de ELISA não apresentavam manchas nos frutos. As manchas brancas (Figura 1A) nos frutos de meloeiro, também, chamadas de "pano branco do melão" devem ser consideradas nos programas de melhoramento, visando a seleção de híbridos ou cultivares resistentes ao WMV-2, uma vez que esta sintomatologia atípica não parece estar associada à severidade dos sintomas nas folhas das plantas infetadas. Embora haja referências de que o WMV-2 afeta a produção e a qualidade dos frutos de espécies de cucurbitáceas (Purcifull et al.) CMI/AAB. Description of Plant Vírus n 293. 1984), não existem relatos sobre as manchas nos frutos aqui apresentadas. Testes de ELISA-indireto com mais de 500 sementes pré-germinadas coletadas de melão com mancha branca revelaram a ausência do WMV-2 nas mesmas, confirmando a não-transmissibilidade deste potyvírus por sementes de melão.

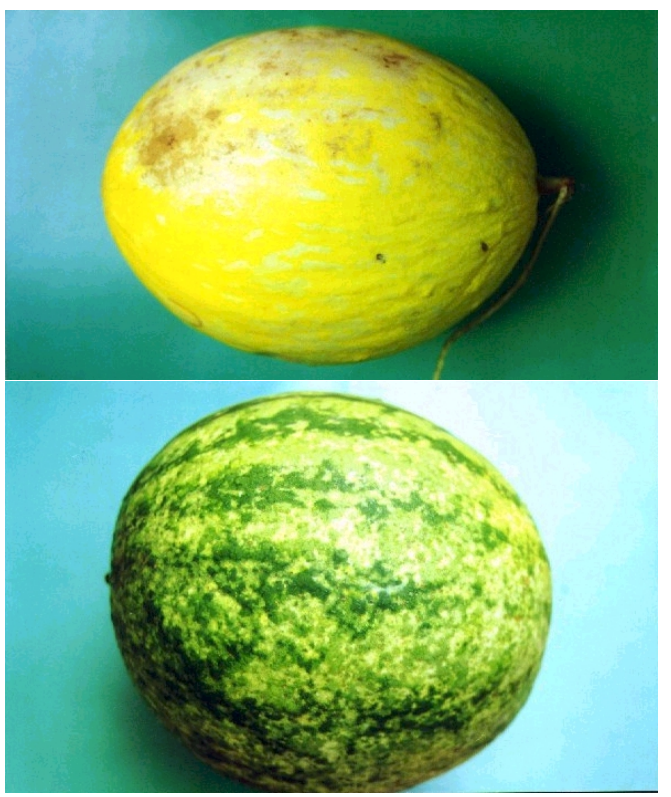

FIG. 1 - Sintomas de mancha branca (A) em frutos de meloeiro (Cucumis melo) 'AF-682' e de bolhosidade e manchas cloróticas $(B)$ em frutos de melancia (Citrullus lanatus) 'Tiffany' ocasionados por Watermelon mosaic virus-2. 